\title{
PREDIKSI FINANCIAL DISTRESS PADA SEKTOR PERTAMBANGAN
}

\author{
Anita Handayani \\ Prodi Manajemen, Fakultas Ekonomi dan Bisnis \\ Universitas Muhammadiyah Gresik
}

\begin{abstract}
Financial distress shows the condition of the company unable to fulfill its smooth obligations. Financial difficulties if not handled properly will bring the company into bankruptcy. Bankruptcy predictions can use the Altman, Springate, Grover, Zmijewski methods. The results showed that the accuracy of the Springate model predicts financial distress by $73 \%$ compared to other models. And sequentially followed by Altman's model of 54\%, and the grover model of 35\% and the last is the zmijewski model of $22 \%$.
\end{abstract}

Keywords: bankruptcy, altman, grover, springate, zmijewski

\section{PENDAHULUAN}

Financial distress menggambarkan kondisi perusahaan yang tidak bisa memenuhi kewajiban lancarnya. Kesulitan keuangan apabila tidak ditangani dengan baik akan membawa perusahaan dalam kebangkrutan. Kebangkrutan adalah suatu kondisi di mana perusahaan sudah tidak mampu lagi mengelola perusahaan dikarenakan kesulitan keuangan yang tinggi. Kebangkrutan perusahaan akan cepat terjadi apabila negara tempat perusahaan itu berada mengalami krisis ekonomi (Almilia dan Herdiningtyas, 2005).

Kondisi financial distress ini bisa menimpa perusahaan mana saja tak terkecuali perusahaan tambang di Indonesia. Pada tahun 2014 pendapatan perusahaan pertambangan batu bara di BEI secara umum mengalami penurunan pada tahun 2014 (www.indonesia-investment.com). Kemudian Tahun 2015 merupakan tahun terburuk bagi sektor pertambangan, di mana 40 perusahaan pertambangan global mencatat kerugian bersih kolektif sebesar US\$27 miliar. Penurunan ini dikarenakan harga komoditas yang turun sebesar 25\% dari tahun sebelumnya (www. pwc.com). Selain itu, tekanan pada sektor pertambangan disebabkan oleh minimnya permin- taan impor batu bara dari global terhadap Indonesia berakibat pada anjloknya ekspor mineral dan batu bara (www.suara.com).

Menurut Prihanthini (2013) menyatakan bahwa apabila perusahaan mengalami posisi kesulitan keuangan bahkan kebangkrutan maka terdapat pihak yang dirugikan, pihak yang dirugikan merupakan pihak yang berkepentingan dengan perusahaan yaitu pihak investor dan kreditor. Oleh karena itu, dibutuhkan suatu model untuk memprediksi pemicu dari kesulitan keuangan perusahaan sebelum perusahaan betulbetul mengalami kebangkrutan.

Model yang bisa digunakan untuk memprediksi keadaan financial distress yaitu model grover, zmijewski (1983), altman Z-score (1968), dan springate (1978). Menurut Prihantiny (2013) model yang memiliki tingkat keakuratan dalam prediksi financial distress adalah model grover, springate, zmijewski, dan altman. Sedangkan menurut penelitian Kurniawati (2014) model yang akurat memperkirakan financial distress adalah model grover, springgate, dan altman.

Berdasarkan penjelasan di atas, penelitian ini untuk mengetahui model yang lebih baik dalam memprediksi financial distress perusahaan sektor 
tambang di Indonesia dengan menggunakan metode grover, zmijewski, springate, dan altman.

\section{TINJAUAN PUSTAKA}

Penelitian Prabowo (2015) yang meneliti tentang analisis perbandingan model altman, springate, zmijewski untuk memberikan prediksi perusahaan yang mengalami kebangkrutan yang delisting di BEI. Hasil penelitian menunjukkan bahwa model yang mampu memprediksi kebangkrutan adalah model altman sebesar $71 \%$, model springate $70 \%$, dan model zmijewski $65 \%$.

Penelitian Kurniawati dan Kholis (2014) yang meneliti tentang prediksi financial distress perusahaan perbankan syariah di Indonesia. Hasil penelitian pada penelitian tersebut yang mampu melakukan prediksi financial distress secara akurat secara berurutan yaitu model grover, model springate, dan model altman.

Sedangkan menurut penelitian dari Prihathini dan Ratnasari (2013) yang meneliti tentang prediksi kebangkrutan dengan model grover, altman, z-score, springate, dan zmijewski di perusahaan makanan dan minuman pada Bursa Efek Indonesia. Hasil penelitian model yang memiliki akurasi tinggi adalah model grover, springate, zmijewski, dan altman.

\section{Laporan Keuangan}

Laporan keuangan adalah informasi tentang kondisi kinerja perusahaan (Fahmi, 2011:22). Selain itu, menurut IAI (2002) laporan keuangan adalah informasi yang berkaitan dengan posisi keuangan, kinerja, dan perubahan posisi keuangan perusahaan yang bisa digunakan dalam pengambilan keputusan ekonomi.

Berdasarkan Ikatan Akuntan Indonesia (2002) maka penerbitan laporan keuangan memiliki tujuan sebagai berikut.
1. Sebagai informasi untuk melakukan investasi dan pemberian kredit oleh potensial investor, investor, dan kreditor.

2. Untuk prospek perolehan kas dan dividen, penjualan atau bunga dari penerimaan, penebusan, atau pinjaman.

3. Informasi tentang sumber daya yang ada di perusahaan.

\section{Financial Distress}

Kesulitan keuangan atau financial distress yaitu suatu keadaan tidak mampu untuk memenuhi kewajibannya yang sudah jatuh tempo. Financial distress berbeda dengan kebangkrutan karena kesulitan keuangan terjadi sebelum kebangkrutan perusahaan, oleh karena itu manajemen perusahaan perlu untuk mengetahui kondisi perusahaan dalam kondisi sehat atau tidak melalui prediksi financial distress.

Faktor penyebab financial distress adalah sebagai berikut (Prabowo, 2015).

1. Kegagalan ekonomi

Pada kondisi ini menunjukkan bahwa pendapatan perusahaan tidak bisa mencukupi biaya untuk kegiatan perusahaan.

2. Kegagalan usaha

Kegagalan usaha digunakan untuk mengumpulkan perusahaan yang telah menghentikan kegiatan operasinya yang dapat berdampak kerugian kreditor.

\section{Model Prediksi Financial Distress}

\section{Model Altman}

Model ini dikembangkan oleh Altman pada tahun 1968. Model altman yang digunakan untuk memprediksi financial distress adalah sebagai berikut:

$$
\begin{aligned}
& \mathrm{Z}=1,2 \mathrm{X} 1+1,4 \mathrm{X} 2+3,3 \mathrm{X} 3+0,6 \mathrm{X} 4+1,0 \mathrm{X} 5 \\
& \text { (Rumus 1) }
\end{aligned}
$$


Keterangan:

X1: Modal kerja/total asset

X2: Laba yang ditahan/total asset

X3: Pendapatan sebelum pajak dan bunga/total asset

X4: Nilai pasar ekuitas/nilai buku dari utang

X5: Penjualan/total asset

Kriteria pengambilan keputusan model altman adalah sebagai berikut.

Tabel 1

Kriteria Pengambilan Keputusan Model Altman

\begin{tabular}{|l|l|}
\hline \multicolumn{1}{|c|}{ Skor } & \multicolumn{1}{c|}{ Keputusan } \\
\hline $\mathrm{Z}>2,9$ & Perusahaan sehat \\
\hline $\mathrm{Z}<1,81$ & $\begin{array}{l}\text { Perusahaan mengalami financial } \\
\text { distress yang sangat tinggi dan } \\
\text { berpeluang besar mengalami } \\
\text { kebangkrutan. }\end{array}$ \\
\hline $1,81<\mathrm{Z}$ Score $<2,99$ & $\begin{array}{l}\text { Perusahaan dalam kondisi grey } \\
\text { area (peluang perusahaan } \\
\text { mengalami kesulitan keuangan } \\
\text { yang bisa diselamatkan dan } \\
\text { mengalami kebangkrutan sama } \\
\text { besarnya). }\end{array}$ \\
\hline
\end{tabular}

\section{Model Springate}

Model springate dikembangkan oleh Springate. Model springate adalah sebagai berikut.

$S$-Score $=1,03 \mathrm{X} 1+3,07 \mathrm{X} 2+0,66 \mathrm{X} 3+0,4 \mathrm{X} 4$

(Rumus 2)

Keterangan:

$\mathrm{X} 1=$ Modal Kerja terhadap total aset

$\mathrm{X} 2$ = Laba sebelum bunga dan pajak terhadap total aset

$\mathrm{X} 3$ = Laba sebelum pajak terhadap kewajiban lancar

$\mathrm{X} 4$ = Penjualan terhadap total aset

Kriteria pengambilan keputusan model springate adalah sebagai berikut.
Tabel 2

Kriteria Pengambilan Keputusan Model Springate

\begin{tabular}{|c|l|}
\hline \multicolumn{1}{|c|}{ Skor } & \multicolumn{1}{c|}{ Keputusan } \\
\hline $\mathrm{S}<0,862$ & $\begin{array}{l}\text { Perusahaan dalam kondisi } \\
\text { financial distress. }\end{array}$ \\
\hline $\mathrm{S}>0,862$ & $\begin{array}{l}\text { Perusahaan dalam keadaan } \\
\text { sehat secara keuangan. }\end{array}$ \\
\hline
\end{tabular}

\section{Model Grover}

Model grover merupakan pengembangan dari model altman. Model ini dikemukakan oleh Jeffrey S Grover. Model grover adalah sebagai berikut:

Score $=1,650 \mathrm{X} 1+3,404 \mathrm{X} 3-0,016 \mathrm{ROA}+0,057$

(Rumus 3)

Keterangan:

$\mathrm{X} 1=$ Working capital/total assets

$\mathrm{X} 3$ = Earnings before interest and taxes/ total assets

$\mathrm{ROA}=$ net income/total asset

Kriteria pengambilan keputusan dalam model grover adalah sebagai berikut.

Tabel 3

Kriteria Pengambilan Keputusan Model Grover

\begin{tabular}{|c|l|}
\hline Skor & \multicolumn{1}{c|}{ Keputusan } \\
\hline$\leq-0,02$ & $\begin{array}{l}\text { Perusahaan dalam kondisi } \\
\text { bangkrut }\end{array}$ \\
\hline$\geq 0,01$ & $\begin{array}{l}\text { Perusahaan tidak } \\
\text { mengalami kebangkrutan }\end{array}$ \\
\hline
\end{tabular}

\section{Model Zmijewski}

Model keempat untuk melakukan prediksi kondisi keuangan perusahaan yaitu model zmijewski. Model ini dikembangkan oleh Zmijewski pada tahun 1983. Model zmijewski adalah sebagai berikut.

Score $=-4,3-4,5 \mathrm{X} 1+5,7 \mathrm{X} 2-0,004 \mathrm{X} 3$ (rumus 4) 
Keterangan:

$\mathrm{X} 1=$ Return on asset

$\mathrm{X} 2$ = Leverage (debt ratio)

$\mathrm{X} 3=$ Likuiditas (current ratio)

Kriteria pengambilan keputusan untuk model zmijewski adalah sebagai berikut.

Tabel 4

Kriteria Pengambilan Keputusan Model Zmijewski

\begin{tabular}{|c|l|}
\hline Skor & \multicolumn{1}{|c|}{ Keputusan } \\
\hline$>0$ & $\begin{array}{l}\text { Perusahaan potensi mengalami } \\
\text { financial distress }\end{array}$ \\
\hline$<0$ & $\begin{array}{l}\text { Perusahaan diprediksi tidak } \\
\text { berpotensi mengalami financial } \\
\text { distress }\end{array}$ \\
\hline
\end{tabular}

Kerangka Berpikir

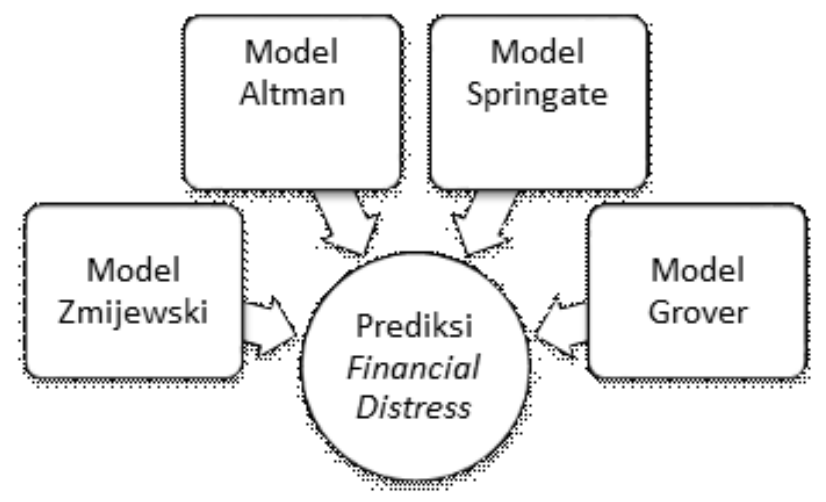

Gambar 1 Kerangka Berpikir

\section{Hipotesis}

1. Model altman paling mampu memprediksi financial distress pada perusahaan tambang yang terdaftar di bursa efek Indonesia.

2. Model springate paling mampu memprediksi financial distress pada perusahaan tambang yang terdaftar di bursa efek Indonesia.

3. Model zmijewski paling mampu memprediksi financial distress pada perusahaan tambang yang terdaftar di bursa efek Indonesia.

4. Model grover merupakan paling mampu memprediksi financial distress pada perusa- haan tambang yang terdaftar di bursa efek Indonesia.

\section{METODOLOGI PENELITIAN}

\section{Jenis Penelitian}

Penelitian kuantitatif, yaitu penelitian dengan data dalam bentuk angka untuk mendapatkan informasi yang digunakan untuk menganalisis model-model prediktor kesulitan keuangan perusahaan pertambangan yang di Indonesia.

\section{Lokasi Penelitian}

Lokasi penelitian ada di Galeri Investasi Fakultas Ekonomi dan Bisnis, Universitas Muhammadiyah Gresik, Jl. Sumatera no 101 Gresik Kota Baru (GKB), Gresik.

\section{Populasi dan Sampel}

Populasi merupakan keseluruhan dari subjek yang digunakan dalam penelitian. Penelitian ini menggunakan populasi yaitu keseluruhan perusahaan tambang yang tercatat di Bursa Efek Indonesia pada tahun 2015 .

Teknik pengambilan sampel yang digunakan yaitu purposive sampling. Di mana teknik pengambilan sampel dengan kriteria tertentu. Kriteria dalam penelitian ini adalah laporan keuangan sektor pertambangan yang telah diaudit tahun 2015.

\section{Definisi Operasional}

Definisi operasional mencakup tentang model yang digunakan untuk prediksi financial distress pada sektor pertambangan adalah sebagai berikut.

1. Model altman, model yang digunakan dengan menggunakan rumus (1), dengan kriteria: 
Tabel 5 Model Altman

\begin{tabular}{|c|c|}
\hline Skor & Keputusan \\
\hline$Z>2,9$ & Perusahaan sehat \\
\hline $\mathrm{Z}<1,81$ & $\begin{array}{l}\text { Perusahaan mengalami } \\
\text { kesulitan keuangan yang } \\
\text { sangat tinggi dan berpeluang } \\
\text { besar mengalami } \\
\text { kebangkrutan }\end{array}$ \\
\hline $1,81<$ Z Score $<2,99$ & $\begin{array}{l}\text { Perusahaan dalam kondisi } \\
\text { grey area (peluang } \\
\text { perusahaan mengalami } \\
\text { kesulitan keuangan yang } \\
\text { bisa diselamatkan dan } \\
\text { mengalami kebangkrutan } \\
\text { sama besarnya) }\end{array}$ \\
\hline
\end{tabular}

2. Model springate, yaitu model yang digunakan dengan menggunakan rumus (2) dengan kriteria sebagai berikut.

Tabel 6 Model Springate

\begin{tabular}{|c|l|}
\hline Skor & \multicolumn{1}{c|}{ Keputusan } \\
\hline $\mathrm{S}<0,862$ & $\begin{array}{l}\text { Perusahaan dalam kondisi } \\
\text { financial distress }\end{array}$ \\
\hline $\mathrm{S}>0,862$ & $\begin{array}{l}\text { Perusahaan dalam keadaan } \\
\text { sehat secara keuangan }\end{array}$ \\
\hline
\end{tabular}

3. Model grover, yaitu model yang digunakan dengan menggunakan rumus (3) dengan kriteria sebagai berikut.

Tabel 7 Model Grover

\begin{tabular}{|c|l|}
\hline Skor & \multicolumn{1}{|c|}{ Keputusan } \\
\hline$\leq-0,02$ & $\begin{array}{l}\text { Perusahaan dalam kondisi } \\
\text { bangkrut }\end{array}$ \\
\hline$\geq 0,01$ & $\begin{array}{l}\text { Perusahaan tidak mengalami } \\
\text { kebangkrutan }\end{array}$ \\
\hline
\end{tabular}

4. Model zmijewski, yaitu model yang digunakan dengan menggunakan rumus (4) dengan kriteria sebagai berikut.

Tabel 8 Model Zmijewski

\begin{tabular}{|c|l|}
\hline Skor & \multicolumn{1}{|c|}{ Keputusan } \\
\hline$>0$ & $\begin{array}{l}\text { Perusahaan potensi mengalami finan- } \\
\text { cial distress }\end{array}$ \\
\hline$<0$ & $\begin{array}{l}\text { Perusahaan diprediksi tidak berpotensi } \\
\text { mengalami financial distress }\end{array}$ \\
\hline
\end{tabular}

\section{Jenis dan Sumber Data}

Data yang digunakan untuk menyelesaikan penelitian menggunakan data sekunder, yaitu data yang didapatkan tidak secara langsung. Data sekunder yang digunakan berupa laporan keuangan perusahaan tambang yang ada di Bursa Efek Indonesia tahun 2015 yang telah diaudit dan diperoleh dari www.idx.co.id.

\section{Teknik Pengambilan Data}

Teknik pengambilan data menggunakan metode dokumentasi dengan mengumpulkan datadata yang dibutuhkan yaitu neraca dan laporan laba rugi yang diperoleh dari website bursa efek Indonesia.

\section{Teknik Analisis Data}

Teknik analisis yang digunakan adalah dengan teknik analisis deskriptif. Di mana teknik ini adalah dengan menjabarkan atau mendeskripsikan dari masing-masing model yang digunakan yaitu model altman, springate, zwijewski, dan grover untuk memprediksi financial distress pada perusahaan tambang di Indonesia. Di mana langkah-langkah dalam penelitian ini adalah sebagai berikut.

1. Mengumpulkan data yang dibutuhkan

2. Melakukan perhitungan sesuai dengan model yang digunakan dalam penelitian ini

3. Melakukan analisis dari setiap model

4. Melakukan peringkat model prediksi financial distress

\section{HASIL DAN PEMBAHASAN}

\section{Model Altman}

Hasil penelitian menggunakan model altman adalah sebagai berikut. 
Tabel 9

Hasil Penelitian Model Altman

\begin{tabular}{|c|c|c|c|c|c|c|c|}
\hline $\begin{array}{c}\text { Model } \\
\text { Financial } \\
\text { Distress }\end{array}$ & \multicolumn{2}{|c|}{ Prediksi Distress } & \multicolumn{2}{|c|}{$\begin{array}{c}\text { Prediksi Non- } \\
\text { Distress }\end{array}$} & \multicolumn{2}{|c|}{ Grey Area } & Total \\
\hline & $\begin{array}{c}\text { Jumlah } \\
\text { Perusahaan }\end{array}$ & $\%$ & $\begin{array}{c}\text { Jumlah } \\
\text { Perusahaan }\end{array}$ & $\%$ & $\begin{array}{c}\text { Jumlah } \\
\text { Perusahaan }\end{array}$ & $\%$ & \\
\hline $\begin{array}{l}\text { Model } \\
\text { Altman }\end{array}$ & 20 & $54 \%$ & 13 & $35 \%$ & 4 & $11 \%$ & 37 \\
\hline
\end{tabular}

Sumber: lampiran, data diolah.

Berdasarkan Tabel 9 model altman mampu memprediksi perusahaan pertambangan di Indonesia yang mengalami distress sebesar 20 perusahaan dan yang non distress sebesar 13 perusahaan dan yang masuk dalam kriteria abuabu sebesar 4 perusahaan.

\section{Model Springate}

Hasil penelitian dengan menggunakan model springate adalah sebagai berikut.

Tabel 10

Hasil Penelitian Model Springate

\begin{tabular}{|c|c|c|c|c|c|c|c|}
\hline $\begin{array}{c}\text { Model } \\
\text { Financial } \\
\text { Distress }\end{array}$ & \multicolumn{2}{|c|}{ Prediksi Distress } & \multicolumn{2}{|c|}{$\begin{array}{c}\text { Prediski Non- } \\
\text { Distress }\end{array}$} & \multicolumn{2}{|c|}{ Grey Area } & Total \\
\hline & $\begin{array}{c}\text { Jumlah } \\
\text { Perusahaan }\end{array}$ & $\%$ & $\begin{array}{c}\text { Jumlah } \\
\text { Perusahaan }\end{array}$ & $\%$ & $\begin{array}{c}\text { Jumlah } \\
\text { Perusahaan }\end{array}$ & $\%$ & \\
\hline $\begin{array}{l}\text { Model } \\
\text { Springate }\end{array}$ & 27 & $73 \%$ & 10 & $27 \%$ & - & - & 37 \\
\hline
\end{tabular}

Sumber: lampiran, data diolah

Berdasarkan Tabel 10 model springate mampu memprediksi perusahaan pertambangan yang tercatat di Indonesia, perusahaan yang mengalami financial distress yaitu sebesar 27 perusahaan dan yang tidak mengalami financial distress sebesar 10 .

\section{Model Grover}

Hasil penelitian menggunakan model grover adalah sebagai berikut.
Tabel 11

Hasil Penelitian Model Grover

\begin{tabular}{|c|c|c|c|c|c|c|c|}
\hline $\begin{array}{c}\text { Model } \\
\text { Financial } \\
\text { Distress }\end{array}$ & \multicolumn{2}{|c|}{ Prediksi Distress } & \multicolumn{2}{|c|}{$\begin{array}{c}\text { Prediski Non- } \\
\text { Distress }\end{array}$} & \multicolumn{2}{|c|}{ Grey Area } & Total \\
\hline & $\begin{array}{c}\text { Jumlah } \\
\text { Perusahaan }\end{array}$ & $\%$ & $\begin{array}{c}\text { Jumlah } \\
\text { Perusahaan }\end{array}$ & $\%$ & $\begin{array}{c}\text { Jumlah } \\
\text { Perusahaan }\end{array}$ & $\%$ & \\
\hline $\begin{array}{l}\text { Model } \\
\text { Grover }\end{array}$ & 13 & $35 \%$ & 24 & $65 \%$ & - & - & 37 \\
\hline
\end{tabular}

Sumber: lampiran, data diolah.

Berdasarkan Tabel 11 model grover mampu memprediksi perusahaan pertambangan yang, mengalami financial distress sebesar 13 perusahaan dan yang tidak mengalami financial distress sebesar 24 .

\section{Model Zmijewski}

Hasil penelitian menggunakan model zmijewski adalah sebagai berikut.

Tabel 12

Hasil Penelitian Model Zmijewski

\begin{tabular}{|l|c|c|c|c|c|c|c|}
\hline $\begin{array}{c}\text { Model } \\
\text { Financial } \\
\text { Distress }\end{array}$ & \multicolumn{2}{|c|}{ Prediksi Distress } & \multicolumn{2}{|c|}{$\begin{array}{c}\text { Prediski Non- } \\
\text { Distress }\end{array}$} & \multicolumn{2}{|c|}{ Grey Area } & Total \\
\hline & $\begin{array}{c}\text { Jumlah } \\
\text { Perusahaan }\end{array}$ & $\%$ & $\begin{array}{c}\text { Jumlah } \\
\text { Perusahaan }\end{array}$ & $\%$ & $\begin{array}{c}\text { Jumlah } \\
\text { Perusahaan }\end{array}$ & $\%$ & \\
\hline $\begin{array}{l}\text { Model } \\
\text { Zmijewski }\end{array}$ & 8 & $22 \%$ & 29 & $78 \%$ & - & - & 37 \\
\hline
\end{tabular}

Sumber: lampiran, data diolah.

Berdasarkan Tabel 12 model zmijewski mampu memprediksi perusahaan pertambangan yang mengalami financial distress sebesar 8 perusahaan dan yang tidak mengalami financial distress sebesar 29, sedangkan tidak ada yang masuk dalam kriteria grey area.

\section{Pembahasan}

Berdasarkan deskripsi hasil penelitian di atas maka ringkasan untuk hasil penelitian tentang model yang digunakan untuk memprediksi financial distress pada perusahaan tambang yang 
terdaftar di Bursa Efek Indonesia tahun 2015 adalah sebagai berikut.

Tabel 13

Ringkasan Hasil Penelitian

\begin{tabular}{|l|c|c|c|c|c|c|c|}
\hline $\begin{array}{c}\text { Model } \\
\text { Financial } \\
\text { Distress }\end{array}$ & \multicolumn{2}{|c|}{ Prediksi Distress } & \multicolumn{2}{|c|}{$\begin{array}{c}\text { Prediski Non- } \\
\text { Distress }\end{array}$} & \multicolumn{2}{|c|}{ Grey Area } & Total \\
\hline & $\begin{array}{c}\text { Jumlah } \\
\text { Perusahaan }\end{array}$ & $\%$ & $\begin{array}{c}\text { Jumlah } \\
\text { Perusahaan }\end{array}$ & $\%$ & $\begin{array}{c}\text { Jumlah } \\
\text { Perusahaan }\end{array}$ & $\%$ & \\
\hline $\begin{array}{l}\text { Model } \\
\text { Altman }\end{array}$ & 20 & $54 \%$ & 13 & $35 \%$ & 4 & $11 \%$ & 37 \\
\hline $\begin{array}{l}\text { Model } \\
\text { Springate }\end{array}$ & 27 & $73 \%$ & 10 & $27 \%$ & - & - & 37 \\
\hline $\begin{array}{l}\text { Model } \\
\text { Grover }\end{array}$ & 13 & $35 \%$ & 24 & $65 \%$ & - & - & 37 \\
\hline $\begin{array}{l}\text { Model } \\
\text { Zmijewski }\end{array}$ & 8 & $22 \%$ & 29 & $78 \%$ & - & - & 37 \\
\hline
\end{tabular}

Sumber: lampiran, data diolah

Berdasarkan Tabel 13 di atas dari masingmasing model memiliki tiga prediksi yaitu prediksi financial distress, non-financial distress, dan grey area. Terlihat bahwa masing-masing model memiliki hasil yang bervariasi dalam memberikan gambaran kondisi financial distress perusahaan pertambangan yang tercatat di Bursa Efek Indonesia tahun 2015. Model yang mampu memprediksi kondisi financial distress yang paling akurat adalah model springate yaitu sebesar 27 perusahaan atau $73 \%$ perusahaan yang menghadapi kondisi financial distress, sedangkan perusahaan yang tidak dalam kategori financial distress adalah $27 \%$ atau sebesar 10 perusahaan.

\section{Perbandingan Model}

Tabel 14

Perbandingan Model Prediksi Financial Distress

\begin{tabular}{|l|c|c|}
\hline \multicolumn{1}{|c|}{$\begin{array}{c}\text { Model Prediksi } \\
\text { Financial Distress }\end{array}$} & $\begin{array}{c}\text { Tingkat } \\
\text { Keakuratan }\end{array}$ & Peringkat \\
\hline Model Springate & $73 \%$ & 1 \\
\hline Model Altman & $54 \%$ & 2 \\
\hline Model Grover & $35 \%$ & 3 \\
\hline Model Zmijewski & $22 \%$ & 4 \\
\hline
\end{tabular}

Sumber: lampiran, data diolah
Berdasarkan semua perhitungan yang telah dilakukan kesimpulan yang bisa diambil adalah dari keempat model di atas, model yang mampu memberikan gambaran tentang kondisi financial distress perusahaan pertambangan yang ada di Indonesia tahun 2015 adalah model springate, dengan tingkat keakuratan adalah sebesar $73 \%$. Posisi kedua yaitu model altman dengan kemampuan prediksinya adalah 54\%, urutan ketiga adalah model grover sebesar $35 \%$, posisi terakhir adalah model zmijewski hanya sebesar $22 \%$ dalam memprediksi financial distress. Oleh karena itu, model springate adalah model yang paling mampu menunjukkan financial distress pada perusahaan tambang yang terdaftar di Bursa Efek Indonesia adalah model springate.

\section{KESIMPULAN DAN SARAN}

\section{Kesimpulan}

Kesimpulan yang bisa diangkat yang bersumber pada pengujian yang telah dilakukan dalam penelitian ini adalah sebagai berikut.

1. Berdasarkan empat model yang digunakan yaitu model springate, altman, zmijewski, dan grover memiliki hasil yang berbeda dalam memprediksi financial distress perusahaan tambang di Indonesia.

2. Model springate memiliki tingkat keakuratan dalam memprediksi financial distress sebesar 73\% dibandingkan dengan model yang lain. Secara berurutan diikuti oleh model altman sebesar 54\%, model grover sebesar 35\%, dan yang terakhir adalah model zmijewski sebesar 22\%. Dengan demikian, model yang paling akurat adalah model springate.

\section{Saran}

Saran yang bisa digunakan untuk memenuhi khazanah penelitian yang berikutnya adalah da- 
pat menambahkan jumlah periode penelitian yang lebih panjang dan menambah jumlah sampel penelitian yang lebih besar serta memasukkan kondisi makroekonomi, dan karakteristik industri dalam variabel penentu financial distress perusahaan.

\section{DAFTAR RUJUKAN}

Almilia dan Winny Herdiningtyas. 2002. Analisis Rasio CAMEL terhadap Kondisi Bermasalah pada Lembaga Perbankan Periode 2000-2002. Jurnal Akuntansi Keuangan, Vol. 7, No.2.

Fahmi, Irham. 2011. Analisis kinerja keuangan. Bandung: Alfabeta

http://www.indonesia-investments.com/id/berita/ berita-hari-ini/pendapatan-usaha tambangbatubara-turun-karena-harga-rendah/item 5384? Diakses pada 15 Februari 2017, pukul 16.00.

http://www.pwc.com/id/en/media-centre/pwc-innews/2016/indonesian/pwctahun-2015sebagai-tahun-terburuk-bagi-sektor-pertambangan.html, diakses pada 15 Februari 2017, pukul 15.00. http://www.suara.com/bisnis/2016/02/07/203637/ ini-2-penyebabindustri pertambangan-nasional-terpukul, diakses pada 15 Februari 2017, pukul 16.15.

Ikatan Akuntansi Indonesia. 2002. Standar Akuntansi Keuangan per 1 April 2002. Jakarta: Salemba Empat.

Kurniawati dan Kholis. 2014. Analisis Model Prediksi Financial Distress pada Perusahaan Perbankan Syariah di Indonesia. Call Paper Syariah Paper Accounting FEB UMS, ISSN 2460-0784.

Prabowo, dan Wibowo. 2015. Analisis Perbandingan Model Altman Z-Score, Zmijewski, dan Springate dalam Memprediksi Kebangkrutan Perusahaan Delisting di BEI periode 2008-2013. Jurnal Akuntansi, Keuangan, dan Perbankan, Vol. 1, No. 3, Juni 2015.

Prihanthini dan Ratnasari. 2013. Prediksi Kebangkrutan dengan Model Grover, Altman Z Score, Springate, dan Zmijewski pada Perusahaan Food and Baverages di Bursa Efek Indonesia. E-Jurnal Akuntansi Universitas Udayana, 5.22013. 